\title{
The Sensitivity and Specificity of GERD Score Questionnaire in Detecting the Prevalence of GERD among Children with Recurrent Secretory Otitis Media
}

\author{
Reham F. Zittoon ${ }^{1,2^{*}}$, Mohamed H. Badereldin ${ }^{1,2}$, Sarah A. Kamel ${ }^{1,3}$ \\ Department of Otorhinolaryngology ${ }^{1}$, Suez Canal University Hospital', Ismailia, Suez General Hospital, Suez³, \\ Egypt
}

\begin{abstract}
Background: Gastroesoghageal Reflux and Otitis Media are two of the most prevalent diseases in young children. Aim: To describe the prevalence of Gastroesophageal reflux in infants and young children with recurrent secretory otitis media. Patients and Methods: This descriptive cross sectional study cross sectional included Ninety-one children of both sex aged from 3 months to 8 years were assessed with history of recurrent secretory otitis media type B Tympanometry not improved completely by medical treatment. X-ray of the nasopharynx was done. The parent or legal guardian completed the Infant Gastroesophageal Reflux QuestionnaireRevised (I-GERQ-R) symptom-based 11 points questionnaire (I-GERQ GERD). Results: this study include 61 male (67\%) and 33 female (33\%) and mean GERD score in patients with GER was $(7.23 \pm$ $3.1)$ compared to Non-GERD group $(0.76 \pm 0.83)(p<0.001)$. The mean GERD score in patients with GER was $5.98+\mid-4.22$ compared to GERD with adenoid group $(3.87 \pm 2.45)$ and Non-GERD group $(0.76 \pm 0.83)(p<0.001)$. GERQ score $\geq 7$ had a sensitivity of $96.2 \%$ and specificity of $98 \%$ in diagnosing GERD among our patients with overall accuracy of $97 \%$. Conclusion: The I-GERQ-R is thus adequately sensitive to be used diagnostically to screen children for symptom burden.
\end{abstract}

Keywords: Gastroesoghageal Reflux, Recurrent Secretory Otitis Media, Children.

\section{Introduction}

Otitis media with effusion (OME) is the most common cause of acquired hearing loss in children. It occurs in approximately $15 \%$ of children 2 to 7 years of age. The etiology of chronic OME is multifactorial, yet the main cause seems to be the dysfunction and impaired patency of the Eustachian tube. One of the factors taken into consideration is Gastroesophageal reflux
$(G E R)^{(1)}$. Reflux of gastric contents beyond the esophagus into the oropharynx, larynx, tracheobronchial tree, and nasopharynx leads to extraesophageal manifestations of Gastroesophageal reflux disease GERD $^{(2)}$. GERD is a common physiologic occurrence in infants and decreases in frequency during the first year of life. Pediatric middle ear disease often coexists with GERD. The size and shape of the immature Eustachian tube may contribute to 
an increase in reflux of nasopharyngeal contents into the middle ear. The functional derangement of OME is believed to involve metaplasia of the middle ear epithelium with a proliferation of goblet cells and mucous glands, leading to hypersecretion, mucociliary dysfunction, and middle ear effusion with concomitant conductive hearing loss. An analogous process may be implicated in other disorders, such as pediatric sinusitis. In that disease, improvement with empiric antireflux therapy has been demonstrated in up to $85 \%$ of children studied, with a decrease in the number of necessary surgical procedures $^{(3)}$. Because GERD and OME are 2 of the most prevalent diseases in young children, a number of investigators have taken preliminary steps to demonstrate a causative link between both diseases. Of particular interest has been the presence of gastric enzymes in the middle ear space. Studies on rats with repeated middle ear exposure to pepsin have demonstrated impaired eustachian tube function as well as impaired mucociliary clearance of middle ear contents ${ }^{(3)}$. The study aimed to describe the prevalence of Gastroesophageal reflux in infants and young children with recurrent secretory otitis media at Suez Canal University Hospital, Ismailia city.

\section{Patients and Methods}

Study design

A descriptive cross-sectional study was carried out in Otorhinolaryngology Clinic at Suez Canal University Hospital, Ismalia City from February 2019 to February 2021.

\section{Study population}

Patients under study were selected by randomization from patients attending otolaryngology clinic in Suez Canal university hospital who were diagnosed as hav- ing otitis media with effusion by clinical criteria of OME by otoscopic examination (tympanic membrane retraction, fluid level) and by flat curve type by tympanogram that persistent more than 3 months.

Inclusion criteria: Children aged between 3 months and 8 years of Both genders who had 1) Three episodes of secretory otitis media in the past 6 months, or 4 in the past 12 months. 2) Three months of bilateral middle ear effusion tympanometry Type B not improved completely by medical treatment. 3) Patients with reflux symptoms and 4) Grade 1 or 2 adenoid hyperplasia.

\section{Exclusion criteria}

Children with previous myringotomy or ventilation tube surgery, any nasal polyps, congenital anomalies especially craniofacial abnormality or severely atelectatic tympanic membrane. Children who had been treated with antireflux medications 6 weeks before the study, those with Grade 3 or 4 adenoid hyperplasi (as it is lead to closure of eustachian tube) or have type c tympanometry.

\section{Methods}

Ninety-one children of both sexes aged from 3 months and 8 years were assessed from May 2018 to June 2019 with history of Recurrent secretory otitis media type $B$ Tympanometry not completely improved by medical treatment at otorhinolaryngology clinic, Suez Canal University hospital. X-ray lateral view on the soft tissue of the nasopharynx was done to diagnose adenoid hyperplasia in suspected patients. The parent or legal guardian answered questions asked by the researcher according to the Infant Gastroesophageal Reflux Questionnaire-Revised (I-GERQ-R) symptom-based 11 points questionnaire (I- 
GERQ GERD) with maximum score of 25 to differentiate GER from GERD and have shown that a score of $>7$ has $74 \%$ sensitivity and $94 \%$ specificity in diagnosing GERD in infants. This questionnaire was applied in Indian population(4) and has shown to be easily adaptable and reproducible but had lower diagnostic accuracy (sensitivity of $43 \%$ and specificity of $79 \%$ ) than the original study and has shown to be easily adaptable and reproducible (sensitivity of $43 \%$ and specificity of $79 \%$ ), can be used to segregate those who needs empirical therapy or further investigation(5).

\section{Statistical Analysis}

The collected data was revised, coded, tabulated and introduced to a PC using Statistical package for Social Science (SPSS 23). Data was presented and suitable analysis was done according to the type of data obtained for each parameter. Descriptive statistics included Mean, Standard deviation ( \pm SD) and range for parametric numerical data, while Median and Interquartile range (IQR) for nonparametric numerical data. Frequency and percentage of non-numerical data. While analytical statistics included Chi-square $\left(\mathrm{X}^{2}\right)$ test of significance was used in order to compare proportions between two qualitative parameters or fisher-exact test. Independent t test was used to identify the possible association between the numerical variables. Results were considered statistically significant at a P-value less than 0.05. ROC curve analysis was done to assess the validity of GER questionnaire in diagnosing GERD in our study patients.

\section{Results}

Table 1 describes demographic characteristics of the patients with mean age of 46 months it ranged from 6 to 96 months.
Males represent $67 \%$ of the study participants and females represent 33\%. Table 2 shows that $71.4 \%$ of patients had episodes of otitis media in the last six months, while the others $28.6 \%$ had episodes of otitis media in the last twelve months. All the patients had tympanometry $\mathrm{B}$.

Table 1: Demographic characteristics of patients $(n=91)$.

\begin{tabular}{|c|c|}
\hline Characteristics & \\
\hline $\begin{array}{c}\text { Age } \\
\text { (Mean } \pm \text { SD) months } \\
\text { Range }\end{array}$ & $\begin{array}{c}(46 \pm 24) \\
(6-96)\end{array}$ \\
\hline Gender No (\%) & \\
\hline Male & $61(67 \%)$ \\
\hline Female & $30(33 \%)$ \\
\hline
\end{tabular}

Table 3 shows that $64.8 \%$ had adenoid and allergy symptoms, $44 \%$ of patients had regurgitation, $39.6 \%$ had vomiting, $30.8 \%$ had irritability, $33 \%$ had congestion, $17.6 \%$ had cough, $2.2 \%$ had hoarseness of voice, and $7.7 \%$ had arching.

Table 2: History of episodes among patients $(n=91)$

\begin{tabular}{|l|c|c|}
\hline & No & $\%$ \\
\hline Episode of OM in last 6 months & 65 & 71.4 \\
\hline Episode of OM in last 12 months & 26 & 28.6 \\
\hline Tympanometry B & 91 & 100 \\
\hline
\end{tabular}

Table 4 shows the distribution of component of I-GERQ among patients in which $33 \%$ of patients had spitting up with 1-3 times per day in $20.9 \%$ of patients and $>5$ times per day in $4.4 \%$ and from 1 teaspoonful to 1 tablespoonful in $24.2 \%$ of patients. 45.1\% had Chocking/ Gagging, 36.3\% had Irritability/ Fussiness, 39.6\% had Refusal to feed up, $37.4 \%$ had trouble gaining enough weight, $33 \%$ was crying during or after feeding, $6.6 \%$ had episodes of hiccups, $7.7 \%$ had arching back and no patients had struggling to breath. The patients had a mean score of $(7.25 \pm 6.4)$ 
ranged from 0 to 25. Table 5 showed that the prevalence of GERD among Secretory OM patients is $67 \%$ and non-GERD $33 \%$.

Table 3: Clinical data of the patients $(\mathrm{n}=91)$

\begin{tabular}{|l|c|c|}
\hline GERD symptoms & No & $\%$ \\
\hline Regurgitation & 40 & 44 \\
\hline Vomiting & 36 & 39.6 \\
\hline Irritability & 28 & 30.8 \\
\hline Congestion & 30 & 33 \\
\hline Cough & 16 & 17.6 \\
\hline Hoarseness of voice & 2 & 2.2 \\
\hline Arching & 7 & 7.7 \\
\hline Stridor & 0 & 0 \\
\hline $\begin{array}{l}\text { Adenoid hyperplasia and } \\
\text { allergy symptoms }\end{array}$ & 59 & 64.8 \\
\hline
\end{tabular}

Table 6 showed that the prevalence of GERD among OM patients is 67\%. GERD only group was $28.6 \%$, GERD with adenoid hyperplasia $38.4 \%$, while Non-GERD group was $33 \%$. Table 7 showed that three groups had statistical insignificant age and gender difference. Table 8 showed that there was statistical insignificant difference regarding episodes of $\mathrm{OM}$ in the last 6 and 12 months. Table 9 showed that GERD group had significantly higher percentage of patients with regurgitation, vomiting, irritability, cough, and congestion. Table 10 showed that three groups had statistical insignificant difference in irritability, cough, congestion, and hoarseness of voice. GERD group showed higher percentage of patients with regurgitation and vomiting than other two groups with statistically significant differences. Table 11 showed that GERD group has statistically significant higher percentage of patients with spitting up and it's frequency and volume than other groups. Also, GERD group has statistically significant higher percentage of patients with chocking/gagging, irritability/fussiness, refusal to feed up, crying during or after feeding, episodes of hiccups and arching back than the other group. The mean GERD score in patients with GER was $(7.23 \pm 3.1)$ Compared to Non-GERD group $(0.76 \pm 0.83)(p<0.001)$. Table 12 showed that GERD group and GERD with adenoid group had statistically significant higher percentage of patients with spitting up and it's frequency and volume than other groups. Also, GERD group and GERD with adenoid group had statistically significant higher percentage of patients with chocking/gagging, irritability/fussiness, refusal to feed up, crying during or after feeding, episodes of hiccups and arching back than the other group. The mean GERD score in patients with GER was $5.98+/-4.22$ compared to GERD with adenoid group $(3.87 \pm 2.45)$ and Non-GERD group $(0.76 \pm 0.83)(p<0.001)$. GERQ score $\geq 7$ had a sensitivity of $96.2 \%$ and specificity of $98 \%$ in diagnosing GERD among our patients with overall accuracy of $97 \%$ (Table 13).

Table 4: Data of I-GER questionnaire

\begin{tabular}{|c|c|c|}
\hline $\begin{array}{l}\text { I-GER questionnaire } \\
\text { ( } \mathrm{n}=91 \text { patients) }\end{array}$ & No & $\%$ \\
\hline Spitting up & 30 & 33 \\
\hline \multicolumn{3}{|l|}{ Spitting up times } \\
\hline$\cdot 1$ to 3 times per day & 19 & 20.9 \\
\hline - 3 to 5 times per day & 7 & 7.7 \\
\hline - $>5$ times/day & 4 & 4.4 \\
\hline \multicolumn{3}{|l|}{ Spitting up volume } \\
\hline $\begin{array}{l}-1 \text { teaspoonful to } 1 \text { table- } \\
\text { spoonful }\end{array}$ & 22 & 24.2 \\
\hline $\begin{array}{l}-1 \text { tablespoonful to } 1 \\
\text { ounce }\end{array}$ & 8 & 8.8 \\
\hline$\cdot>1$ ounce & 0 & 0 \\
\hline Chocking/Gagging & 41 & 45.1 \\
\hline Irritability/Fussiness & 33 & 36.3 \\
\hline Refusal to feed up & 36 & 39.6 \\
\hline Trouble gaining enough weight & 34 & 37.4 \\
\hline Crying during or after feeding & 30 & 33 \\
\hline Episodes of Hiccups & 6 & 6.6 \\
\hline Arching back & 7 & 7.7 \\
\hline Struggling to breath & 0 & 0 \\
\hline $\begin{array}{l}\text { Total score }(\text { mean } \pm S D) \\
\text { Range }\end{array}$ & \multicolumn{2}{|c|}{$\begin{array}{c}7.25 \pm 6.4 \\
(0-25)\end{array}$} \\
\hline
\end{tabular}




\begin{tabular}{|l|c|c|}
\hline \multicolumn{3}{|c|}{$\begin{array}{c}\text { Table 5: Prevalence of GERD } \\
\text { among patients ( } \mathrm{n}=91)\end{array}$} \\
\hline & No & $\%$ \\
\hline GERD group & 61 & 67 \\
\hline Non-GERD group & 30 & 33 \\
\hline Total & 91 & 100 \\
\hline
\end{tabular}

\begin{tabular}{|l|c|c|}
\hline $\begin{array}{c}\text { Table 6: Prevalence of GERD sub groups } \\
\text { among patients ( } \mathrm{n}=91)\end{array}$ \\
\hline & No & $\%$ \\
\hline GERD only group & 26 & 28.6 \\
\hline GERD with adenoid group & 35 & 38.4 \\
\hline Non-GERD group & 30 & 33 \\
\hline Total & 91 & 100 \\
\hline
\end{tabular}

\section{Discussion}

In the present study, children with OME were assessed for the prevalence of GERD and it was found that $67 \%$ (61 of 91 children) with OME had GERD. However, symptom descriptions of GERD are nonspecific and unreliable in infants and young children and esophageal $\mathrm{pH}$ monitoring, is a valid and reliable measure of acid exposure in evaluating GERD in children with secretory OM. In our study diagnosis of GERD based on a 25-point infant GERD score with 11 signs and symptoms of gastroesophageal reflux (GER) as previously suggested(5).

Table 7: Demographic characteristics of study groups.

\begin{tabular}{|l|c|c|c|c|c|}
\hline Characteristics & $\begin{array}{c}\text { GERD } \\
\text { group } \\
(\mathrm{n}=26)\end{array}$ & $\begin{array}{c}\text { GERD with ad- } \\
\text { enoid group } \\
(\mathrm{n}=35)\end{array}$ & $\begin{array}{c}\text { Non GERD } \\
\text { group } \\
(\mathrm{n}=30)\end{array}$ & $\begin{array}{c}\text { Test } \\
\text { value }\end{array}$ & P-value \\
\cline { 1 - 3 } $\begin{array}{l}\text { Age } \\
\text { Rean } \pm \text { SD) months } \\
\text { Range }\end{array}$ & $\begin{array}{c}40.4 \pm 22.3 \\
12-96\end{array}$ & $\begin{array}{c}46.7 \pm 24.5 \\
6-96\end{array}$ & $\begin{array}{c}45.3 \pm 23.2 \\
6-96\end{array}$ & 1.306 & $\mathbf{0 . 1 9 5}$ \\
\cline { 1 - 3 } \begin{tabular}{l} 
Gender \\
\multicolumn{1}{|c|}{ Male }
\end{tabular} & $20(76.9 \%)$ & $21(60 \%)$ & $20(66.7 \%)$ & 1.611 & $\mathbf{0 . 2 2 9}$ \\
\hline \multicolumn{1}{|c|}{ Female } & $6(23.1 \%)$ & $14(40 \%)$ & $10(33.3 \%)$ & \\
\hline
\end{tabular}

Table 8: History of episodes among study groups

\begin{tabular}{|l|c|c|c|c|c|}
\hline & $\begin{array}{c}\text { GERD } \\
\text { group } \\
(\mathrm{n}=26)\end{array}$ & $\begin{array}{c}\text { GERD with } \\
\text { adenoid } \\
\text { group } \\
(\mathrm{n}=35)\end{array}$ & $\begin{array}{c}\text { Non GERD } \\
\text { group } \\
(\mathrm{n}=30)\end{array}$ & $\begin{array}{c}\text { Test } \\
\text { value }\end{array}$ & P-value \\
\hline Episode of OM in last 6 months & $18(69.2 \%)$ & $21(60 \%)$ & $20(66.7 \%)$ & 0.086 & 0.769 \\
\hline Episode of OM in last 12 months & $8(30.8 \%)$ & $14(40 \%)$ & $10(33.3 \%)$ & 0.086 & 0.769 \\
\hline Tympanometry B & $26(100 \%)$ & $35(100 \%)$ & $30(100 \%)$ & 0.00 & 1.00 \\
\hline
\end{tabular}

In our study the mean GERD score with GERD was $5.98+/-4.22$ compared NonGERD group $(0.76 \pm 0.83)(p<0.05)$. The mean GERD score in Aggarwal et al(4) study in infants with GER was $4.64+/-3.99$ compared to $3.54+/-3.96$ in those with no documented GER $(p<0.05)$. We found that
GERQ score $\geq 7$ had a sensitivity of $96.2 \%$ and specificity of $98 \%$ in diagnosing GERD among our patients with overall accuracy of $97 \%$. A GERD score of 5 had a sensitivity of $43 \%$ and specificity of $79 \%$, compared to $86 \%$ and $85 \%$ observed by Orenstein et al(5) in their series. The I-GERQ- $R$ is thus ade- 
quately sensitive to be used diagnostically to screen children for symptom burden, but should probably be supplemented by other, perhaps invasive, testing to assure appropriate specificity. The I-GERQ-R's validation for evaluative properties, however, supports its use for tracking symptoms within clinical trials(5). The prevalence of GERD in children with OME in our study is similar to previous reports. In Velepic et $\mathrm{al}^{(6)}$ study reported $60 \%$, Rozmanic et al(7)
$55.5 \%$, Keles et al ${ }^{(8)} 64 \%$, Serra et al(9) $54.3 \%$. In a study by Yüksel et al ${ }^{(10)}$ reported that $54.9 \%$ of children with the symptoms of hearing loss or aural fullness and diagnosed as OME by examination and tympanometry had GERD as Children were reviewed gastroesophageal reflux disease symptoms and least one positive test of radionuclide gastroesophageal scintigraphy or $24 \mathrm{~h} \mathrm{pH}$ probe in the patients with reflux.

Table 9: Clinical data of the study groups $(n=91)$.

\begin{tabular}{|l|c|c|c|c|}
\hline GERD symptoms & $\begin{array}{c}\text { GERD group } \\
(\mathrm{n}=61)\end{array}$ & $\begin{array}{c}\text { Non GERD group } \\
(\mathrm{n}=30)\end{array}$ & Test value & P-value \\
\hline Regurgitation & $40(65.6 \%)$ & $\mathrm{O}(0 \%)$ & 24.33 & $<0.001$ \\
\hline Vomiting & $36(59 \%)$ & $\mathrm{o}(0 \%)$ & 21.54 & $<0.001$ \\
\hline Irritability & $26(42.6 \%)$ & $2(6.7 \%)$ & 18.24 & $<0.001$ \\
\hline Congestion & $29(47.5 \%)$ & $4(13.3 \%)$ & 19.82 & $<0.001$ \\
\hline Cough & $10(16.4 \%)$ & $6(20 \%)$ & 4.42 & 0.021 \\
\hline Hoarseness of voice & $2(3.3 \%)$ & $0(0 \%)$ & 1.76 & 0.054 \\
\hline
\end{tabular}

Table 10: Clinical data of the study sub groups $(n=91)$.

\begin{tabular}{|l|c|c|c|c|c|}
\hline \multirow{2}{*}{ GERD symptoms } & \multicolumn{2}{|c|}{ GERD sub groups } & Non GERD & Test \\
\cline { 2 - 5 } & $\begin{array}{c}\text { GERD group } \\
(\mathrm{n}=26)\end{array}$ & $\begin{array}{c}\text { GERD with adenoid } \\
\text { group } \\
(\mathrm{n}=35)\end{array}$ & $\begin{array}{c}\text { Proup } \\
(\mathrm{n}=30)\end{array}$ & $\begin{array}{c}\text { value } \\
\text { Revalue }\end{array}$ & $\mathrm{0}$ \\
\hline Regurgitation & $21(80.8 \%)$ & $19(54.3 \%)$ & $0(0 \%)$ & 5.446 & 0.004 \\
\hline Vomiting & $20(76.9 \%)$ & $16(45.7 \%)$ & $0(0 \%)$ & 6.107 & 0.002 \\
\hline Irritability & $6(23.1 \%)$ & $20(57.1 \%)$ & $2(6.7 \%)$ & 1.011 & 0.315 \\
\hline Congestion & $8(30.8 \%)$ & $18(51.4 \%)$ & $4(13.3 \%)$ & 0.08 & 0.778 \\
\hline Cough & $6(23.1 \%)$ & $4(11.4 \%)$ & $6(20 \%)$ & 0.758 & 0.384 \\
\hline Hoarseness of voice & $2(7.7 \%)$ & $0(0 \%)$ & $0(0 \%)$ & 5.11 & 0.079 \\
\hline
\end{tabular}

In a systematic review by Miura et al ${ }^{(11)}$ a mean prevalence of GERD in children with Recurrent Secretory OM was reported to be $48.4 \%$. In the other hand, Abd El-Fattah et $\mathrm{al}^{(12)}$ reported that only three of 17 studied children with OME had GER, this was lower than our results and reports in our studies. The differences between these results can be explained by the differ- ences in age of studied children and difference in methodology. The difference in methodology is that they were submitted to ventilation tubes as well as adenoidectomy/tonsillectomy, and after recovery from surgery, $\mathrm{pH}$ monitoring was performed. As the effect of these procedures on GER are not well-established, it seems that the most appropriate time for $\mathrm{pH}$ 
monitoring would be before surgical interventions, in the presence of chronic $\mathrm{OM}^{(12)}$. In Abtahi et $\mathrm{al}^{(13)}$ study about "Prevalence and characteristics of gastroesophageal reflux in children with otitis media in Isfahan, Iran" which found The prevalence of GER in children with Chronic Secretory OM in our study was $72.7 \%$. and found that the most common symptoms in the studied children with OM were regurgitation, vomiting, irritability, congestion, cough and feeding complex as they asked about current symptoms that may be suggestive of GERD, using validated questionnaires. These questionnaires included the two age-stratified versions of the pediatric GERD symptoms for children
2 years old and younger, and children 3-7 years old. In our study GERD group showed higher percentage of patients with regurgitation and vomiting than non GERD group with statistical significant differences. In agreement with Abtahi et $\mathrm{al}^{(13)}$ study. We found in our study that there is relation between GERD and adenoid hyperplasia as 35 of 91 have adenoid hyperplasia and most common symptoms of GERD as regurgitation, vomiting ,irritability ,congestion and cough as found in Keles et $\mathrm{al}^{(8)}$ that The risk of development of adenoid hyperplasia was established 9.6 more times in children having GERD, whereas, it was 5.4 more times in children having GERD.

Table 11: Data of I-GERQ among study groups

\begin{tabular}{|c|c|c|c|c|}
\hline I-GERQ & $\begin{array}{l}\text { GERD group } \\
\qquad(n=61)\end{array}$ & $\begin{array}{c}\text { Non } \\
\text { GERD group } \\
(n=30)\end{array}$ & $\begin{array}{l}\text { Test } \\
\text { value }\end{array}$ & P-value \\
\hline Spitting up & $30(49.2 \%)$ & $\mathrm{o}(0 \%)$ & 34.36 & $<0.001$ \\
\hline \multicolumn{5}{|l|}{ Spitting up times } \\
\hline - 1 to 3 times per day & $19(31.1 \%)$ & $\mathrm{O}(0 \%)$ & \multirow[t]{3}{*}{22.07} & \multirow[t]{3}{*}{$<0.001$} \\
\hline - 3 to 5 times per day & $7(11.5 \%)$ & $\mathrm{O}(0 \%)$ & & \\
\hline - > 5 times/day & $4(6.6 \%)$ & $0(0 \%)$ & & \\
\hline \multicolumn{5}{|l|}{ Spitting up volume } \\
\hline - 1 teaspoonful to 1 tablespoonful & $22(36.1 \%)$ & $\mathrm{O}(0 \%)$ & \multirow{3}{*}{53.17} & \multirow{3}{*}{$<0.001$} \\
\hline - 1 tablespoonful to 1 ounce & $8(13.1 \%)$ & $\mathrm{O}(0 \%)$ & & \\
\hline - >1 ounce & 0 & $\mathrm{o}(0 \%)$ & & \\
\hline Chocking/Gagging & $41(67.2 \%)$ & $\mathrm{O}(0 \%)$ & 67.76 & $<0.001$ \\
\hline Irritability/Fussiness & $30(49.2 \%)$ & $3(10 \%)$ & 32.21 & $<0.001$ \\
\hline Refusal to feed up & $30(49.2 \%)$ & $6(20 \%)$ & 29.74 & $<0.001$ \\
\hline Trouble gaining enough weight & $28(45.9 \%)$ & $6(20 \%)$ & 23.23 & $<0.001$ \\
\hline Crying during or after feeding & $30(49.2 \%)$ & $\mathrm{o}(0 \%)$ & 34.36 & $<0.001$ \\
\hline Episodes of Hiccups & $6(14.6 \%)$ & $\mathrm{O}(0 \%)$ & 10.49 & 0.006 \\
\hline Arching back & $7(11.5 \%)$ & $\mathrm{O}(0 \%)$ & 27.44 & $<0.001$ \\
\hline Struggling to breath & $\mathrm{o}(0 \%)$ & $0(0 \%)$ & 0.00 & 1.00 \\
\hline Total score & $7.23 \pm 3.1$ & $0.76 \pm 0.83$ & 42.43 & $<0.001$ \\
\hline
\end{tabular}

\section{Conclusion}

The I-GERQ- $R$ is thus adequately sensitive to be used diagnostically to screen child- ren for symptom burden, but should probably be supplemented by other, perhaps invasive, testing to assure appropriate specificity. The I-GERQ-R's validation for evaluative properties, however, sup- 
ports its use for tracking symptoms within clinical trials. The IGER Questionnaire is easily adaptable and reproducible in the settings of developing countries. These results supported that pharyngeal reflux may play an important role in the etiology of adenoid hyperplasia

Table 12: Data of I-GERQ among study sub groups.

\begin{tabular}{|c|c|c|c|c|c|}
\hline I-GERQ & $\begin{array}{l}\text { GERD } \\
\text { group } \\
(\mathrm{n}=26)\end{array}$ & $\begin{array}{l}\text { GERD with ade- } \\
\text { noid group } \\
(\mathrm{n}=35)\end{array}$ & $\begin{array}{l}\text { Non } \\
\text { GERD } \\
\text { group } \\
(\mathrm{n}=30)\end{array}$ & $\begin{array}{l}\text { Test } \\
\text { value }\end{array}$ & $\begin{array}{c}\mathrm{P}- \\
\text { value }\end{array}$ \\
\hline Spitting up & $18(69.2 \%)$ & $12(34.3 \%)$ & $0(0 \%)$ & 55.48 & $<0.001$ \\
\hline \multicolumn{6}{|l|}{ Spitting up times } \\
\hline$\bullet 1$ to 3 times per day & $11(42.3 \%)$ & $8(22.9 \%)$ & $0(0 \%)$ & \multirow[t]{3}{*}{52.07} & \multirow[t]{3}{*}{$<0.001$} \\
\hline - 3 to 5 times per day & $4(15.4 \%)$ & $3(8.6 \%)$ & $\mathrm{o}(0 \%)$ & & \\
\hline$\bullet>5$ times/day & $3(11.5 \%)$ & $1(2.8 \%)$ & $\mathrm{o}(0 \%)$ & & \\
\hline \multicolumn{6}{|l|}{ Spitting up volume } \\
\hline $\begin{array}{l}\text { - } 1 \text { teaspoonful to } 1 \text { ta- } \\
\text { blespoonful }\end{array}$ & $14(53.8 \%)$ & $8(22.9 \%)$ & $\mathrm{O}(0 \%)$ & \multirow{3}{*}{53.17} & \multirow[t]{3}{*}{$<0.001$} \\
\hline $\begin{array}{l}\text { - } 1 \text { tablespoonful to } 1 \\
\text { ounce }\end{array}$ & $4(15.4 \%)$ & $4(11.4 \%)$ & $0(0 \%)$ & & \\
\hline$\bullet>1$ ounce & 0 & $\mathrm{o}(0 \%)$ & $0(0 \%)$ & & \\
\hline Chocking/Gagging & $20(76.9 \%)$ & $21(60 \%)$ & $0(0 \%)$ & 67.76 & $<0.001$ \\
\hline Irritability/Fussiness & $16(61.5 \%)$ & $14(40 \%)$ & $3(10 \%)$ & 49.98 & $<0.001$ \\
\hline Refusal to feed up & $16(61.5 \%)$ & $14(40 \%)$ & $6(20 \%)$ & 49.98 & $<0.001$ \\
\hline Trouble gaining enough weight & $14(53.8 \%)$ & $14(40 \%)$ & $6(20 \%)$ & 3.107 & 0.078 \\
\hline Crying during or after feeding & $16(61.5 \%)$ & $14(40 \%)$ & $0(0 \%)$ & 49.98 & $<0.001$ \\
\hline Episodes of Hiccups & $4(15.4 \%)$ & $2(5.7 \%)$ & $\mathrm{O}(0 \%)$ & 10.49 & 0.006 \\
\hline Arching back & $5(19.2 \%)$ & $2(5.7 \%)$ & $0(0 \%)$ & 27.44 & $<0.001$ \\
\hline Struggling to breath & $0(0 \%)$ & $0(0 \%)$ & $0(0 \%)$ & 0.00 & 1.00 \\
\hline Total score & $5.98 \pm 4.22$ & $3.87 \pm 2.45$ & $0.76 \pm 0.83$ & 28.93 & $<0.001$ \\
\hline
\end{tabular}

Table 13: validity of I-GERQ diagnosing GERD

\begin{tabular}{|l|c|c|c|c|c|c|}
\hline Variable & Cut-off & $\begin{array}{c}\text { Sensitivity } \\
(\%)\end{array}$ & $\begin{array}{c}\text { Specificity } \\
(\%)\end{array}$ & $\begin{array}{c}\text { PPV } \\
(\%)\end{array}$ & $\begin{array}{c}\text { NPV } \\
(\%)\end{array}$ & $\begin{array}{c}\text { Accuracy } \\
(\%)\end{array}$ \\
\hline GERQ score & $\geq 7$ & 96.2 & 98 & 97.9 & 96.3 & 97 \\
\hline
\end{tabular}

\section{References}

1. American Academy of Family Physicians, American Academy of Otolaryngology-Head and Neck Surgery, American Academy of Pediatrics Subcommittee on Otitis Media with Effusion. Otitis media with effusion. Pediatrics 2004:113:1412-1429.

2. Lieu JEC, Muthappan PG, Uppaluri R.
Association of reflux with otitis media in children. Otolaryngol Head Neck Surg. 2005:133(3):357-361.

3. He Z, O'Reilly RC, Bolling L, et al. Detection of gastric pepsin in middle ear fluid of children with otitis media. Otolaryngol Head Neck Surg. 2007: 137(1):59-64

4. Aggarwal, S., Mittal, K., Kalra, K., et al. "Infant gastroesophageal reflux dis- 
ease score: reproducibility and validity in a developing country." Tropical gastroenterology: official journal of the Digestive Diseases Foundation 25.2 2004: 96-98.

\section{ROC Curve}

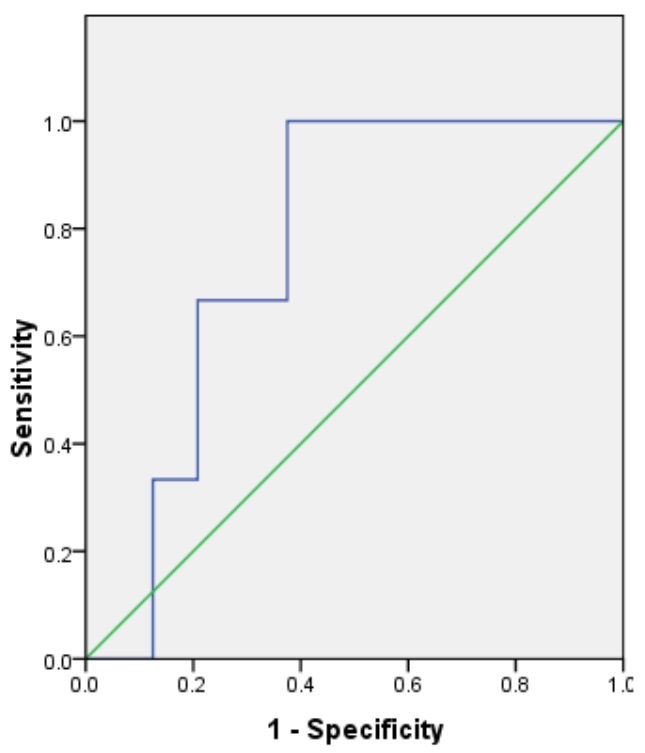

Figure 1: ROC curve for GERQ score in diagnosing GERD

5. Orenstein SR. Symptoms and reflux in infants: Infant Gastroesophageal Reflux Questionnaire Revised (I-GERQR) - utility for symptom tracking and diagnosis. Current gastroenterology reports. 2010 Dec;12(6):431-6.

6. Velepic MM, Velepic MS, Starcevic R, et al. Gastroesophageal reflux and sequelae of chronic tubotympanal disorders in children. Acta Otolaryngol. 2004; 124:914-7
7. Rozmanic $\mathrm{V}$, Velepic $M$, Ahel $\mathrm{V}$, et al. Prolonged esophageal $\mathrm{pH}$ monitoring in the evaluation of gastroesophageal reflux in children with chronic tubotympanal disorders. J Pediatr Gastroenterol Nutr. 2002; 34:278-80.

8. Keles B, Ozturk K, Arbag H, Gunel E, Ozer B. Frequency of pharyngeal reflux in children with adenoid hyperplasia. Int J Pediatr Otorhinolaryngol. 2005; 69:1103-7

9. Serra A, Cocuzza S, Poli G, La Mantia I, Messina A, Pavone P. Otologic findings in children with gastroesophageal reflux. Int J Pediatr Otorhinolaryngol. 2007;71:1693-97.

10. Yüksel F, Dogan M, Karatas D, Yüce S, Sentürk M, Külahli I. Gastroesophageal reflux disease in children with chronic otitis media with effusion. J Craniofac Surg. 2013;24:380-3.

11. Miura MS, Mascaro M, Rosenfeld RM. Association between otitis media and gastroesophageal reflux: A systematic review. Otolaryngol Head Neck Surg. 2012;146:345-52

12. Abd El-Fattah AM, Abdul Maksoud GA, Ramadan AS, Abdalla AF, Abdel Aziz MM. Pepsin assay: A marker for reflux in pediatric glue ear. Otolaryngol Head Neck Surg. 2007; 136:464-70

13. Abtahi SH, Kazerooni A, Brejis N, Abdeyazdan Z, Saneian H. Prevalence and characteristics of gastroesophageal reflux in children with otitis media in Isfahan, Iran. Advanced biomedical research. 2016;5. 
Email address: dr.reham_zittoon@outlook.com 